Deportations and the Roots of Gang Violence in Central America

Christian Ambrosius

School of Business \& Economics

Discussion Paper

Economics

$2018 / 12$ 


\title{
Deportations and the Roots of Gang Violence in Central America
}

This version: June $17^{\text {th }} 2018$

Christian Ambrosius

Freie Universität Berlin \&

UNAM Mexico-City

\begin{abstract}
El Salvador, Honduras and Guatemala count among today's most violent countries of the world. Qualitative research has claimed that large-scale deportations of Central American convicts have played an important role for the spread of gangs and rampant violence in the region. Using a novel identification strategy, this paper provides the first econometric evidence for this hypothesis from the case of El Salvador. Regarding the dependent variable, the policy experiment of a truce between rivaling gangs in 2012 allows to single out gang-related killings from overall homicide rates. The explanatory variable exploits subnational variation in the exposure of migrant communities to exogenous conditions in the host country. Violence spilled over to migrants' places of origin when migrant corridors developed around US destinations with high pre-existing levels of violent crime. The cross-sectional evidence is backed by panel data analysis dating back to 1999. The annual inflow of convicts translated into rising homicides mainly in those municipalities whose migrants were exposed to high pre-existing crime at destination, whereas deportations of non-convicts did not have the same effect. These finding are in line with evidence on the origin of Central American gangs in US cities and convicts' return to their places of birth after massive deportations since the mid-1990s.
\end{abstract}

Keywords: Deportations, Gang Violence, Central America

JEL codes: K42, O15, H8

I am grateful to Jesse Acevedo for sharing data on migration corridors and for very helpful comments, Carlos Carcach for sharing data on historical rates of violence, and Roberto Valencia for sharing data on local level homicide rates. The paper also benefitted from comments by Covadonga Meseguer, Sabine Kurtenbach and participants at the $2^{\text {nd }}$ Conference on Globalization and Development in Göttingen. Errors and omissions are mine, of course. Comments to the manuscript are welcome: Christian.Ambrosius@,fu-berlin.de 
"We sent them children fleeing war and they returned gangs to a country that needed to construct peace" (Carlos Dada, Salvadoran journalist and writer ${ }^{1}$

\section{Introduction}

Gang violence has become a major concern in Central America since the late 1990s. Guatemala, Honduras and El Salvador are consistently ranked among the most violent countries of the world, with average annual homicide rates above 40 per 100,000 in Guatemala and above 60 per 100,000 persons in Honduras and El Salvador over the last ten years, compared to a global average of around 5 (World Bank 2017). The murder rate in El Salvador stood at shocking 109 per 100,000 habitants at its height in 2015, turning El Salvador into the most violent country of the world during that year. In 2017, more than 57\% of Salvadoran citizens ranked delinquency and gangs as their most important concerns, above poverty, unemployment or the economy (Latinobarómetro 2017, 60). Social and economic costs to affected societies are huge. Recent waves in the emigration of unaccompanied minors from Guatemala, Honduras and El Salvador have been attributed to violence at places of origin (Clemens 2017). Although hard to assess in quantitative terms, studies have estimated that direct and indirect monetary costs of gang violence - due to money paid for extortions, the extra amount spent on security, and the lost income of people deterred from working, among others -lie between 11\% of GDP (Acevedo 2008) and 16\% of GDP (BCR 2016).

El Salvador provides a unique laboratory for studying the effects of international migration on the spread of violence at origin. Civil war in the 1980s and subsequent out-migration rapidly transformed Salvadoran economy and society. In 2013, almost 2 million people of Salvadoran origin and 1.2 million Salvadoran-born - roughly a fifth of El Salvador's population of 6 million resided in the US (Pew 2015). Remittances sent by migrants to their families at home contributed to $17 \%$ of Salvadoran GDP in 2016 (World Bank 2017) and have been an important factor in reducing poverty, improving education outcomes, providing liquidity to the financial sector, and financing the current account deficit, among others (Cox Edwards and Ureta 2003; Anzoategui, Demirgüç-Kunt, and Martínez Pería 2014; Gammage 2006). On the dark side of international

\footnotetext{
${ }^{1}$ New York Times (Spanish edition), "El Salvador sacudido por un terremoto llamado Trump", January $12^{\text {th }} 2018$, translated by author.
} 
migration lies the spread of gang-related violence across Central America. Large part of the increase in homicide rates since the 1990s in El Salvador and other Central American countries is related to the activities of two rivaling gangs: The "Mara Salvatrucha" (MS 13) and the $18^{\text {th }}$ street gang (M 18). Both originated on the streets of Los Angeles, Washington and other US metropoles that were home to large Salvadoran Diasporas, nourishing the suspicion that violence in El Salvador and other Central American countries today is rooted in countries' migration histories. Qualitative research and journalistic investigations have emphasized the role that mass deportations of migrants with a criminal record in the US have played for the propagation of gang violence in El Salvador and ultimately in other Central American countries (see for example Arana 2005; Cruz 2013; Lineberger 2011; Maslin 2017; Rodgers, Muggah, and Stevenson 2009; Zuñiga Nuñez 2016). Rodgers et al. $(2009,20)$ suspect that Nicaragua remained spared from the same level of gang violence despite a large Diaspora in the US because its migrant communities were less exposed to US gang culture and therefore experienced much lower deportation rates from the United States. Hard evidence for such assertions is rare, though. In a cross-country panel, Blake (2014) studies the effect of deportations on crime and finds that deportations are correlated with homicide rates in countries of origin, with some evidence for a causal link, using an instrumental variable. At the country level, systematic statistical evidence is absent. To my knowledge, this paper provides the first econometric support to the hypothesis that today's epidemic violence in Central Americas is rooted in countries' migration history.

The identification strategy exploits important geographic variation on key variables unique to the case of El Salvador. Regarding the dependent variable, the policy experiment of a truce that was brokered between rivaling gangs in prison in 2012 led to a temporary drop in homicide rates that allows separating gang-related killings from other homicides. Regarding the independent variable, subnational variation in destination choices of Salvadoran migrants created different levels of exposure to pre-existing rates of violent crime at destination. In Salvadoran municipalities whose migrant communities were exposed to already large pre-existing rates of violence in their host communities upon arrival, destination country violence contaminated migrants' communities of origin, resulting in higher rates of gang-related violence today. This cross-sectional approach is complemented by panel data analysis at the municipal level for the years 1999 to 2016, that provides evidence on the underlying channel of transmission. Annual inflows of convicts translated into higher homicide rates in those municipalities whose migrant communities were exposed to high pre-existing levels of violent crime at destination. The same 
effect is not observed for the inflow of non-criminals, providing additional support to the postulated hypothesis. By including municipality fixed effects, the panel data analysis also responds to the concern that migrants from more violent places of origin might have self-selected into more violent destinations in the US. In sum, although the role of local conditions in facilitating the spread of gangs is not denied, this research singles out an exogenous spark that existed in the form of young immigrants' exposure to pre-existing rates of violent crime in the US. Destination violence spilled over to municipalities of origin where gangs flourished after deportees returned to their places of birth and recruited new members from among the local populations and prisons.

The remainder of the paper is organized as follows: The following Chapter II recounts the history of migration and violence in El Salvador and assesses existing qualitative literature on the links between migration and violence at places of origin. Chapter III describes the data and methods applied. Chapter III presents estimation results for the cross-section of up to 255 Salvadoran municipalities. In chapter IV, these results are backed by panel data regressions on annual homicide rates at the municipal level from 1999 to 2015. Chapter V concludes with remarks on the policy implications of these findings and the potentially huge follow-up costs of deportation policies.

\section{The Roots of Gang Violence in EI Salvador and Central America: Qualitative Evidence}

The history of El Salvador provides a unique opportunity for studying the relationship between international migration and home country violence. In 1992, the guerilla and the military government signed a peace accord that ended a decade of civil war that had taken a death toll of 70,000 (Buergenthal 1994), the displacements of a quarter of the population and a deeply divided country that is still marking El Salvador's political landscape of a two-party system from opposing ends of the political spectrum, representing the former military leaders on the right and the former guerilla on the left.

The armed conflict had initiated a mass exodus in the 1980s, that was further intensified over the 1990s and 2000s. At the onset of the civil war in 1980, international migrants constituted roughly $2 \%$ of the Salvadoran population. By 1990, the share of foreign born Salvadorans in the US had risen to over $8 \%$. By the time the civil war ended in 1992, many immigrants had built an 
important web of community and organizational infrastructure that induced subsequent immigration, increasing its stock of international migrants to $14 \%$ by the year 2000 and to over $18 \%$ of the total Salvadoran population in 2008 (see Figure 1). Foreign-born migrants from El Salvador in the US are today estimated at 1.2 million, or a fifth of the country's population of roughly six million. While providing an escape valve to Salvadorans that helped to reduce poverty and improve living conditions of a large part of the population, out-migration also radically transformed El Salvador's society and economic model (Gammage 2006). The Salvadoran economy today is heavily dependent on out-migration and remittances that contributed to $17 \%$ of GDP in 2016 (World Bank 2017), a model that is threatened by increasingly stricter immigration rules in the US and forced returns of those without legal resident status.

Salvadoran migrant communities often developed in urban areas, with the largest communities developing in the poorer urban districts of Los Angeles, Washington, New York and Houston (PEW 2015; MPI 2010). Vigil (Vigil 2010, 132f) describes how young Salvadorans that had arrived with their parents during the 1980s and 90s were initially attracted to existing Chicano and Latino gangs, but increasingly formed their own Salvador-based gangs, later joined by other Central Americans (cp. Cruz 2013). US prisons and Juvenile Detention Centers have been claimed to have played an important role in shaping a specific "Salvadoran" identity of gangs and their emancipation from older Latino gangs (see Howell and Moore 2010; Howell 2015; Dunn 2007; C. Martínez and Sanz 2012a, 2012b for the creation of Salvadoran gangs in the US). Partly as a response to the involvement of immigrant population in drug trafficking and other illegal gang activities, large-scale deportations of Central Americans began in the mid-1990s. Removals intensified with passage of the Illegal Immigrant Reform and Immigrant Responsibility Act (IIRIRA) in 1996 that expanded the categories of undocumented immigrants subject to deportation and made it more difficult for them to get relief from removal (cp. Seelke 2011). Following the IIRIA act in 1996, any "alien" who served a longer-than-a-year sentence became subject to removal from the U.S. after completion of their prison term (Cruz 2013, 5). As a result, gang-members were directly sent from US jails to El Salvador. Ranking second only after Mexico, El Salvador registered an increasing number of deportations since the early 1990s (see Figure 2). Depending on the year, between a third and half of all deportees had some criminal background, mostly young adults that had grown-up and made criminal careers in US urban metropolis. Overall deportation rates increased further in the 2000s, including non-legal residents 
both with and without prior criminal records. Over the entire 17-year period for which data is available (1997 - 2015), the US deported a total of 244 thousand Salvadorans. Of these, more than 90 thousand -roughly a third - had a criminal background.

Public responses to the spread of gangs in El Salvador were complicated by the fact that Salvadoran authorities received no information on the legal background of returnees ${ }^{2}$. Hence, the Salvadoran state not only lacked the financial resources but was also deprived of the legal means for tracking deportees once they entered Salvadoran territory. In this context, scholars and journalists alike have repeatedly suggested that mass deportation of Salvadorans with a criminal record in the US lies at the root of Central America's curse of gang violence today, by effectively exporting US gangs to Central America (e.g. Arana 2005; Maslin 2017; Seelke 2011). While it is true that juvenile gangs have a tradition that dates back to the time before mass deportations (Smutt and Miranda 1998), international migration and subsequent deportations radically transformed the landscape of Salvadoran gangs. Cruz $(2013,11)$ reports that in survey rounds undertaken by Cruz and Peña (1998) only 4\% and 11\% of interviewed gang members had actually been deported from the US. Yet, they had a large influence on the shape, character and growth of local gangs, not only in terms of cultural attributes, but also in terms of their inner organization and dynamics. Older native gangs were taken over by spin-offs of two dominant US gangs: The MS 13 and the $18^{\text {th }}$ street gang (M18). Within these, deportees took leading roles and recruited new gang members from the streets and in prisons (e.g. Demoscopia 2007, Ranum 2006). As Rodger et al. $(2009,19)$ say: “deportees reproduced the structures and behavior patterns that had provided them with support and security in the United States. They swiftly founded local clikas, or chapters, of their gang in their communities of origin; in turn, these clikas rapidly attracted local youths and either supplanted or absorbed pandillas". In a context of weak statehood and weak law enforcement on the one hand, and high poverty and a lack of employment opportunities on the other hand, gangs and related violence flourished (Savenije 2009; Savenije and Andrade-Eekhoff 2003). By the end of the 1990s and early 2000s, homicide rates had reached levels not previously known. After the break-up of a temporary truce brokered

2 Only in 2014, the State Department and the Department of Homeland Security signed an agreement to expand a Criminal History Information Sharing (CHIS) program with Central American countries (Seelke 2011, 9; Cruz 2013) 
in prison between rivaling gang members in 2012 (Ó. Martínez et al. 2012b), violence peaked in 2015 with a homicide rate of 109 per 100,000, the highest in the world (World Bank 2017). Having started as a local phenomenon, MS13 and $18^{\text {th }}$ street gang acquired a progressively transnational character and spread into neighboring countries and Mexico, posing a major security threat to the region.

[Figure 1: Foreign Born Salvadorans in the US (in thousands), and their Share of Home Country Population, 1960-2008]

[Figure 2: Annual Deportations of Salvadorans, 1997-2016]

\section{Data and Methods}

In order to demonstrate that migrants' exposure to pre-existing violent crime at US destinations contaminated migrants' places of origin, this paper relies on both cross-sectional and timevariation in homicide rates at the level of Salvadoran municipalities.

\section{Modelling Cross-Sectional Variation in Gang-Related Violence}

The following cross-sectional model is estimated for 255 Salvadoran municipalities $\mathrm{j}$ for which data is available ${ }^{3}$ :

(eq. 1) gangrelated killings ${ }_{j}=\beta_{0}+\beta_{1}$ exposure US violence $_{j}+\beta_{2}{\text { Xpre } 92_{j}}+u_{j}$

\footnotetext{
${ }^{3}$ The regression below uses 255 out of a total of 262 Salvadoran municipalities. Seven municipalities dropped from the regression, either because no data on migrants were reported or because the migration channel could not be identified. Six Salvadoran municipalities have repeated names and could not be clearly assigned in the data.
} 
In eq. (1), gangrelated killings refers to an estimate of homicides attributed to gangs, whereas exposure US violence measures the average exposure of each municipality's Diaspora to preexisting crime rates at US destinations. Xpre92 is a vector of pre-treatment control variables measured at the level of Salvadoran municipalities, $\beta$ are the estimated coefficients and $u$ is the usual error term.

In order to distinguish the phenomenon of gang-related violence from overall homicide rates that may have other causes, the dependent variable proxies gang-related killings in each Salvadoran municipality $\mathrm{j}$ by exploiting the quasi-experiment of a truce ${ }^{4}$ that was brokered between rivaling gang members in Salvadoran prisons in march 2012 (Ó. Martínez et al. 2012a). Incarcerated gang leaders who still commanded the two dominant gangs from within prison were offered privileges against the promise to reduce killings. The truce brought average homicide rates considerably down to around 35 per 100,000 people between march 2012 and march $2013^{6}$, halving the average rate of around 70 during the years before (see Figure 3). After the truce broke up in mid$2013^{7}$, homicides jumped to 109 per 100 thousand in 2015 (WDI), the highest rate ever registered in El Salvador, turning the country into the world's most violent country in peace-time. Although the truce was not successful in suppressing gang-related violence over the longer term (post-truce homicide rates were higher than before) the policy experiment provides an opportunity to approximate gang-related violence at the level of municipalities as the difference between homicide rates during the truce (march 2012 - march 2013) and homicide rates before and after the truce. Figure 4 illustrates the estimate of the geographical distribution of gang-related violence in El Salvador, where darker shades indicate a stronger drop in homicide rates during the truce. The figure highlights considerable variation in the effects of the truce at the subnational level, with the strongest drops registered in the Central Western Zone. Data on homicide rates at the level of municipalities for the years 2009 to 2015 is based on information collected by the

${ }^{4}$ This approach has been applied similarly by Kilsi (2017)

${ }^{6}$ Own calculation based on homicide rates reported by the mesa tripartida.

${ }^{7}$ Although the truce was officially abandoned only in January 2015, the truces was already severely weakened after June 2013 (Valencia 2015). Calculations for the reduction in homicide rates is based on the period 03/2012 to 03/2013 during which homicide rates most visibly fell. 
National Police, the Institute of Legal Medicine and the public prosecutor's department (fiscalia) in El Salvador ${ }^{8}$. For the years 1999 to 2008, homicide data at the municipal level is taken from the statistical yearbooks of the Institute for Legal Medicine (Instituto de Medicina Legal de El Salvador. Anuarios Estadísticos).

The rationale behind estimating an effect of migrants' exposure to US violence is that gangs in El Salvador developed when migrant communities settled in urban areas with large pre-existing gang structures and other criminal activities. Once being returned to their places of birth, deportees brought gang practices, habits and criminal skills acquired abroad with them.

In order to create an indicator for Diaspora's exposure to US crime at the level of Salvadoran municipalities, the exposure to crime at destination is weighted by the size of Diasporas in US destination counties. Hence, for every municipality $\mathrm{j}$ the indicator measures calculates the average exposure of its migrant population to violent crime at destination counties $\mathrm{k}$. Whereas data on the size of gangs at a local level is not available for the 1980s, incidents of violent crime including murder and non-negligent manslaughter, legacy rape, revised rape, robbery, and aggravated assault are used as a proxy for the prevalence of gangs. Data for US crime statistics comes from the US Department of Justice-Federal Bureau of Investigation, via US Census Bureau $(2017)^{10}$. Data on migration corridors comes from the North American Integration and Development (NAID) Center at the University of California Los Angeles, who collected crosssectional data on migration corridors between El Salvador and the US up to the level of Salvadoran municipalities and US counties ${ }^{11}$.

\footnotetext{
${ }^{8}$ The National Police, the Institute of Legal Medicine and the public prosecutor's department form the "mesa tripartida" (a tripartite commission) that provides the most reliable information on homicide rates at the municipal level. Data from the mesa tripartida were shared by Roberto Valencia from the online newspaper www.elfaro.net

${ }^{10}$ The average exposure of Salvadoran migrants to crime in the US was about 4-5 times larger than the average US crime rate (crime rates averaged over all US counties). This can be explained by the fact that Salvadoran migrants settled to a large degree in large cities.

${ }^{11}$ Data collection was completed in 2011 and used to be publicly available under https://gis.ats.ucla.edu/naid/. See Hinojosa (2011) for a description of the data and Anzoategui et
} 
To mitigate the concern that crime rates at destination could themselves be affected by increasing immigration from Latin America since the 1990s, the earliest available year at the county-level will be used, which is 1981. Regressions below also evaluate the effect of different locations in the US, in particular Los Angeles, Washington D.C. and Long Island (New York). According to the sample on migration corridors, more than half of all emigrants were located in one of these three Metropolitan Areas ${ }^{12}$. With the exception of Long Island, all of them were characterized by intense gang activities in the 1980s and 1990s before Salvadoran emigrants arrived (Hagedorn 2008; Howell 2015; Dunn 2007). Especially Los Angeles is often considered to be the "gang capital of the world" (Vigil 2010).

Two additional destination variables are included in order to ensure that the contagion of US crime to municipalities of origin is not driven by other variables at destination. Average housing costs of new buildings at the level of US counties is a proxy for wealth and living costs at migrants' destinations. In addition, the share of Latin origin population at destination measures the previous existence of a Latin American Diaspora. Both variables refer to the year 1980, prior to the arrival of Salvadorans (Construction Division of the US Census and the 1980 Population Census, via US Census Bureau (2017). In addition, the vector of cross-sectional control variables X92 includes a large number of variables related to social and demographic characteristics of municipalities. On the one hand, municipalities with a higher incidence of poverty and social exclusion might be more vulnerable to the spread of gang violence (Savenije and AndradeEekhoff 2003; Savenije 2009), either because few employment opportunities lower the opportunity costs of becoming a gang member, or because social composition and cohesion may matter for how resilient a society is to gang violence. On the other hand, municipal level variables address eventual bias that may occur from self-selection into US destinations. For

al. (2014) for an application to the creation of instruments using migrants' population exposure to labor market shocks in the US. I am grateful to Jesse Acevedo for sharing the data.

${ }^{12}$ Similar to the data reported here, the Migration Policy Institute (2010) states that nearly twothirds of Salvadoran immigrants resided in only six metropolitan areas. In addition to those mentioned in the text, San Francisco, Dallas and Houston are other Metropolitan areas with considerable populations of Salvadoran immigrants. 
example, emigrants from urban areas may have a preference for urban destinations in the US, that also tend to be characterized by higher levels of violent crime.

Control variables for the cross-sectional model refer to the year 1992 when the first national census was carried out, shortly after the end of the civil war. This ensures that control variables are not themselves affected by gang violence spreading the country from the late 1990s onwards. The list of control variables includes average household size, population size (logged in the regression), and population density as controls for differences in demographic conditions. A measure on the share of households with at least one member above the age of 15 who does not know how to read or write is included as a measure of levels of human capital. A composite indicator of average housing quality on a scale between 0 and 1 captures differences in poverty levels, where higher values indicate worse housing quality. The indicator on housing quality gives equal weights to four binary housing measures, following definitions used in Digestyc (2015). In addition, regression control for the share of households in which children under the age of 15 were working. Two variables are related to levels of migration and remittances: The share of households in a municipality that reported emigrants, and the share of households who reported international remittances from migrants abroad. Levels of historical data on homicides at the municipal level are hard to get. Carcach (2008) made an effort of estimating municipal level homicide rates for earlier decades by evaluating homicides reported in the printing press. Although these estimates might be biased towards urban municipalities due to better press coverage, the data functions as a rough proxy for historical differences in violence across regions in El Salvador, controlling for longer historical trends and patterns. Logged historical homicide rates measure the average number of homicides per 100,000 as reported in the years 1965,1975 and 1995.

[Figure 3: Monthly Homicide Rates per 100 thousand persons, 2009-2015]

[Figure 4: Drop in Homicides During Truce, by Municipalities]

The estimation of eq. (1) faces several methodological challenges. First, coefficients could be biased if violence in municipality $\mathrm{j}$ is also affected by violence in adjacent territories. Second, the 
dependent variable of gang-related killings is left-truncated: 45 municipalities either reported no drop in violence or increases in violence during the truce. Third, the estimate of homicide rates is relatively imprecise for small municipalities, with populations as small as several thousand inhabitants in some cases. Indicators on the proxy of gang-related violence should be read with the caveat that this indicator is estimated with a larger error term in small municipalities.

The paper addresses these issues in the following ways. First, regressions include precision weights (inverse variance matrix weights), that give a lower weight to municipalities with small population sizes, taking into account a weaker precision of homicide rates for these observations. Alternatively, results will be shown for subsets excluding municipalities below a critical population threshold. Second, as an alternative to ordinary least squares regression, the paper applies tobit maximum likelihood estimation in order to correctly model the left-censoring of the dependent variable. Third, in order to address the possibility of spatial correlation, the paper follows common practice in the literature on determinants of crime (e.g. Anselin et al. 2000; Baller et al. 2001) and evaluates the inclusion of a spatial lag parameter, that takes into account possible correlation of violence between $\mathrm{k}$ municipalities sharing a common border. Then, a binary weighting matrix is applied to the list of neighbors in order to identify spatial lags for each municipality j.

\section{Modelling Time Dynamics}

Results from the cross-sectional study are backed by an analysis of time-variation in homicide rates at the municipal level, covering the sixteen-years period ranging from 1999 to 2015 that was marked by an overall increase in homicide rates. Unfortunately, detailed data on deportees including their municipalities of birth is not available. However, interacting aggregate numbers of the annual inflow of deportees with characteristics of different migration corridors provides annual variation at the level of municipalities that permits examining several implications and the channel of transmission: If the hypothesis on a contagion of US violent crime along migration corridors via deportations is true, annual inflows of convicts should have a strong effect on homicide rates in municipalities whose Diaspora settled in high-crime environments in the US, and low effects in municipalities whose Diaspora settled in low-crime environments. At the same time, we should not see an effect of an inflow of non-convicts on homicides. Also, in line with eq. (1), we should observe a positive effect of an interaction of annual inflows of deportees with 
high-crime exposure of migrants up the truce in march 2012, and a drop in homicide rates during the years of the truce (2012 and 2013).

These hypotheses will be tested using the following linear panel model:

(eq. 2) homicides h,t $=\beta_{1}$ inflow convicts $*$ exposure US violence $\mathrm{j,t}+\beta_{2} \mathrm{X}_{\mathrm{j}, \mathrm{t}}+\tau_{t}+v_{i}+\mathrm{u}_{\mathrm{j}, \mathrm{t}}$

where homicides refer to logged homicides per 100 thousand persons at time $t$ in municipality $\mathrm{j}$. $\beta_{1}$ is the main coefficient of interest, estimated from an interaction between the annual inflow of deported convicts and the average exposure of migrants from each municipality $\mathrm{j}$ to pre-existing violent crime at US destinations. Data on annual US deportation to El Salvador for are available from the US Department of Homeland Security, Yearbooks of Immigration Statistics (see Figure 2).

Results below also show results for an interaction with the inflow of non-convicts, as well as an interaction with the years of the truce. Next to the year fixed effect $\tau_{t}$ that captures common time trends, the regression also controls for municipality fixed effects $v_{i}$. Hence, all time-constant factors at the municipality level are controlled for, including geographical, institutional and other historical legacies that differ between municipalities. Municipality fixed effects $v_{i}$ reduce the potential threat to identification that may arise if unobserved variables explain both the selfselection into US destination and the prevalence of gang-related killings today.

Annual inflows of deportations are plausibly an exogenous variable, that should not be affected by regional variation in homicide rates within El Salvador. In addition to municipality fixed effects, the vector $\mathrm{X}$ is comprised of two time-varying controls at the level of municipalities. Population size is included as a measure of demographic factors that could be related to migratory movements, among others. In addition, the annual value added tax generated per capita at the level of municipalities controls for economic conditions. As above, $u$ is the usual error term. Data on per capita value added tax generated at the level of municipality is available from the Secretary of Finance (Ministerio de Hacienda de El Salvador, Dirección de Impuestos Internos). The population size at the municipality level is provided by the National Statistics Office (Digestyc 1996; Digestyc/UNFPA/CEPAL 2014). Like in the cross-sectional model, the 
panel model in equation (2) is estimated using precision weights, taking account of the fact that homicide rates are measured with larger errors in small municipalities.

See Annex 1 for a description of all variables and sources.

\section{Cross-Sectional Evidence: Migrants' Exposure to Violent Crime at Destination and Gang-Related Killings in El Salvador}

Table 1 summarizes regression output for the effect of migrants' exposure to US crime rates on gang-related violence from ordinary least squares. Output based on tobit maximum likelihood estimation for left-censored variables and results from a spatial lag models are provided in the appendix. Since left-censoring and spatial lags hardly altered the results, results shown below focus on linear regression results due to its simplicity and easy interpretation ${ }^{20}$.

Results in Table 1 are shown for six different specifications. The first column shows effects of migrants' exposure to crime at destination on gang-related killings, without any additional controls. Colum 2 refers to a subset of municipalities with a population of at least 10,000 in 1992, reducing the sample by more than a half. Column 3 introduces department fixed effects and precision weights, addressing the lower reliance of estimates in small populations. Column 4 adds social and demographic controls from the 1992 household census plus a control for historical homicide rates. Column 5 additionally controls for destination characteristics (i.e. housing costs and share of Latin population). Column 6 excludes all municipalities that belong to the capital and largest city San Salvador.

Social and demographic variables in 1992 do not show a clear pattern with respect to the prevalence of gang-related killings today: None of the variables is statistically significant. A moderate negative effect is found for levels of out-migration: Municipalities with a larger relative

\footnotetext{
${ }^{20}$ For technical reasons, the three methodological challenges mentioned above - left truncation, spatial correlation, and imprecise estimates for small municipalities - are addressed separately. One reason for focusing on the linear regression output with precision weights is that bias resulting from small sample bias turned out to be more relevant compared to truncation and spatial correlation.
} 
number of emigrants in 1992 have a lower level of gang-related violence today. This suggests that it is not migration as such that is related to violence. Population size enters with a negative sign, indicating that a larger drop in violence as a result of the truce was measured in small municipalities. Historical rates of violence are negatively correlated with gang-related killings. Partly, the negative sign should reflect an urban bias in the indicator based on crime reported in the printing press with better coverage of urban areas. With that limitation in mind, available data provides no evidence that historical rates of violence predict current rates of gang-related killings. The one variable that is strongly statistically significant in all regressions is Diasporas' exposure to violent crime at destination. As expected, an exposure to more crime at destination is associated with larger rates of current gang-related homicides (i.e. a stronger reduction in homicides during the truce). Since the variable on exposure to US violent crime has been normalized, the coefficient indicates the expected level of gang-related violence in the most exposed compared to the least exposed municipality. The effect of migrants' exposure is robust to excluding the smallest municipalities (column 2), the inclusion of pre-treatment municipality controls as well as other destination variables (columns 4 and 5), and the exclusion of the Metropolitan area of San Salvador (column 6). Giving a lower weight to small municipalities (precision weights in columns 3 to 6) increases the effect. Figure 5 visualizes output from Table 1 , by drawing the predicted level of gang-related violence from spec. (5) as a function of municipalities' exposure to violent crime in the US with a 95\% confidence interval. Larger circles refer to more populated municipalities, that are given a larger precision weight in the regression. Note that the model predicts negative values at the lowest range, a result of using linear regression on data that should be censored at the left. Since $95 \%$ of municipalities have values above .2 on the $\mathrm{x}$-axis, the OLS predictions hardly differ from the truncated model for the range of interest. See Annex 2 for estimation results based on the tobit model for censored variables.

[Table 1: Exposure to US Violence and Gang-Related Homicides (OLS)]

[Figure 5: Exposure to US Crime and Predicted Gang Violence] 
Table 2 shows results for several additional specifications. Column 1 repeats column 5 from Table 1 but adds several post-treatment variables: Average value added tax per capita raised over the years 2001 to 2012, population size in 2007, the poverty gap in 2005 , and the share of households receiving remittances and the share of households with emigrants in 2007 . Results are robust to the inclusion of these post-treatment variables. Column 3 also controls for the three main destinations of migrants in the US (New York, Washington and Long Island). The coefficient for exposure to US violent crime is hardly affected. The remaining columns 4 to 6 provide estimated coefficients for each of the main destinations in the US separately. As expected, the sign for Long Island is negative (the destination with the lowest levels of violent crime in the 1980s) and the coefficient for Los Angeles is positive (the city with the strongest gang activities). However, none is statistically significant. What drives the result seems to be exposure to violent crime rather than the destination as such.

[Table 2: Exposure to US Violence and Gang-Related Homicides (OLS, Alternative Specifications)]

\section{Evidence from Panel Data}

Several open questions remain from the cross-sectional analysis. For one, while establishing a correlation between migrants' exposure to crime in the US and current gang-related violence, the actual channel of transmission - deportations of convicts - is unobserved. Second, municipalities might self-select into more violent destinations in the US. Unobserved omitted variables may pose a threat to identification, if these explain both the self-selection into US destination and the

prevalence of gang-related killings today. For example, migrants from urban municipalities might self-select into urban destination with large crime, but urban municipalities might also be more prone to criminal activities.

In response to these concerns, this section provides additional evidence for the postulated hypotheses. For one, by analyzing time-dynamics of homicide rates over the period 1999 to 2015 , homicide rates can be related to annual deportations. Total annual deportations (see Figure 2) are 
calculated as rates per 100 thousand persons in the regression below ${ }^{21}$. Although the inflow of deportees towards specific municipalities is unknown, the interaction of aggregate deportations from the US to El Salvador with the exposure to US violent crime provides time-variation at the level of municipalities. As mentioned above, the inflow of convicts is expected to affect homicide rates primarily in municipalities with high exposure to US crime. Second, the inclusion of municipality fixed effects permits to control for all time-invariant variables that could be related to self-selection into migrants' destination.

Table 3 shows results from linear panel regressions with municipality and year fixed effects for seven specifications. The baseline regression in column 1 estimates the interaction between the inflow of convicts and the exposure to US violence from 1999 up to the truce in 2012. Column 2 extends the sample to 2015, and includes an interaction of exposure to US violence with truce years. Column 3 adds precision weights. Column 4 adds controls (value added tax per capita and population size). Column 5 adds an interaction with the inflow of non-convicts. Column 6 excludes the Metropolitan area of San Salvador. Column 7 is based on two-year intervals instead of annual data.

[Table 3: Annual Deportations and Homicide Rates at the Municipal Level. Panel Results (OLS)]

All results are as expected and confirm the pattern found in the cross-sectional analysis. The inflow of convicts translates into higher homicide rates in municipalities with a stronger exposure to US violent crime (column 1). In line with the cross-sectional analysis, the truce led to a drop in homicides in municipalities with a high exposure to violent crime in the US (column 2). The effect increases when the low precision of small population estimates is addressed via precision weights (column 3). Also including economic and demographic controls increases the effect of an inflow of convicts in municipalities with high exposure to US violent crime (column 4). In contrast, the coefficient for the interacted inflow of non-convicts has a much smaller size and is statistically insignificant in column 5. Excluding the Metropolitan area of San Salvador hardly

${ }^{21}$ Deportation rates per 100 thousand over the entire period ranged between 30 and 150 for convicts, and between 30 and 280 for non-convicts. 
affects the outcome (column 6), whereas using two-year intervals instead of yearly intervals diminishes the size of the coefficients, but not their statistical significance (column 7).

How many homicides can be attributed to the inflow of convicts? While the model does not identify an average effect of deportations on homicide rates, comparing effects of an inflow of convicts in municipalities with high and low exposure to US violence does provide some information on the magnitude of contagion. For example, based on column 4, we would expect one more homicide per 100 thousand persons in the most exposed municipality compared to the least exposed municipality, for an inflow of 10 additional convicts per 100 thousand persons.

\section{Conclusion}

The two gangs that dominate violence in El Salvador - the MS 13 and the $18^{\text {th }}$ street gang (M18) - originated in US cities. Previous qualitative research and journalistic investigations have claimed that deportations of convicted gang members who had mostly come as children of immigrants and were socialized into existing gang cultures at their places of arrival had a strong influence on the spread of gang violence in Central America. This paper adds the first econometric evidence to the hypothesis on violence contagion: The larger migrants' exposure to pre-existing violence at destination, the more gang-related homicides at their places of origin. This observation is backed by an analysis of time-dynamics. The annual inflow of convicts translated into increasing homicide rates mostly in those municipalities whose migrants were exposed to high levels of violent crime at US destinations. The fact that the same is not observed for the inflow of migrants without a penal record in the US provides additional evidence for the contagion of violence via deported convicts.

This is not a denial of country conditions that favored the spread of gang-related violence in Central America. Social exclusion, lack of employment opportunities, weak state capacities, and possibly a tradition of violence that dated back to the civil war and before posed fertile grounds for the extension of gangs and the recruitment of new members from among the local population. However, the goal of this research was to trace the roots of gang-related violence to El Salvador's migration history and to single out an exogenous spark that consisted in migrants' exposure to crime in the US. 
The Salvadoran experience bears important lessons for current debates on deportation policies in destination countries of immigrants. In the case of Central America, the huge long-term social and economic costs of deportation policies can hardly be assessed in quantitative terms. They pose a serious obstacle to the development of the affected countries and are the major cause of recent emigration waves from the Northern triangle in Central America (Honduras, Guatemala and El Salvador) to the US, particularly of unaccompanied minors (Clemens 2017). Whereas contexts may differ, this study should be read as a warning also against deportation policies in other countries and contexts. Parallels may exist, for example, to the forced return of suspected terrorists towards countries that may lack capacities and resources to control and contain criminal activities. 


\section{Tables and Figures}

Figure 1: Foreign Born Salvadorans in the US (in thousands), and their Share of Home Country

Population, 1960-2008

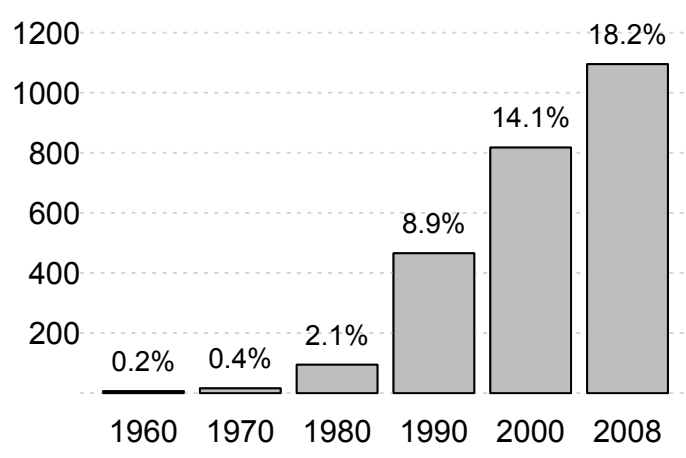

Source: Pew Research Center (2015)

Figure 2: Annual Deportations of Salvadorans, 1997-2015

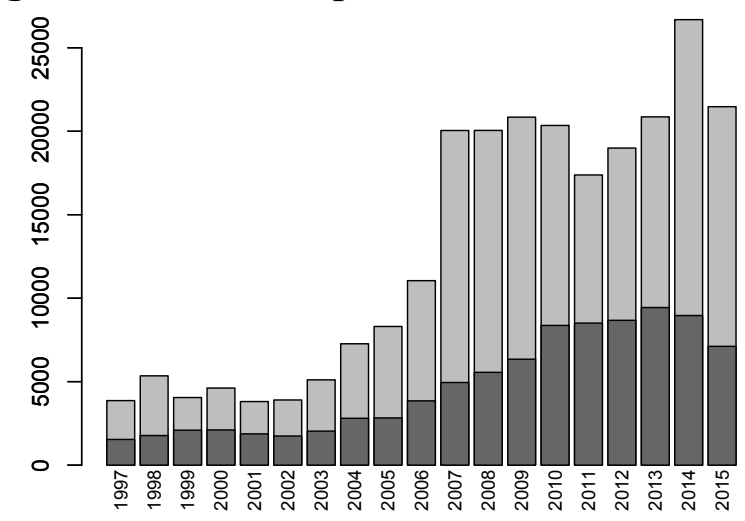

The figure shows total annual deportations of Salvadorans from the US (grey bars) and, as a subset, those who had been convicted (dark grey bars). Source: US Department of Homeland Security, Yearbooks of Immigration Statistics, Various Years 
Figure 3: Monthly Homicide Rates per 100 thousand persons, 2009-2016

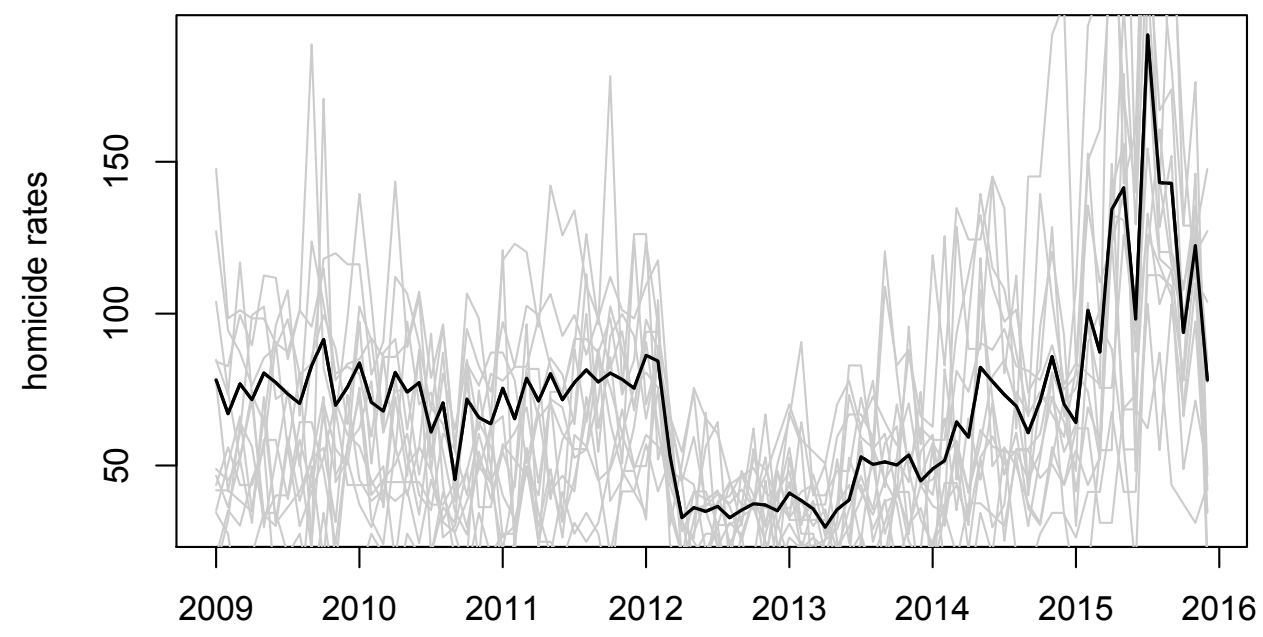

The figure shows annualized homicide rates per 100 thousand persons at the level of Salvadoran municipalities (light grey lines) and as an average over all municipalities (black line). The truce between rivaling gang members was brokered in march 2013 and faded out in June 2013. See text for details and sources.

Figure 4: Drop in Homicides During Truce, by Municipalities

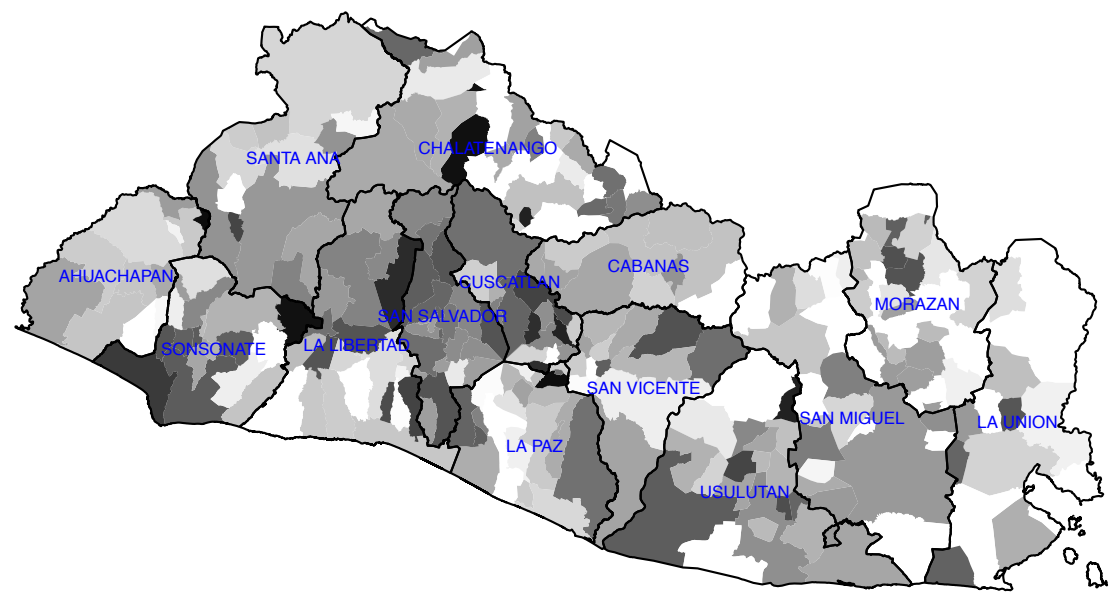

Darker shades indicate a higher drop in homicide rates during the truce between rivaling gangs (march 2012-march 2013). The drop in homicides rates is used as a proxy for the spatial distribution of gang-related homicides. The estimate less precise for small municipalities, an issue to be addressed in the empirical strategy. See text for details. 
Table 1: Exposure to US Violence and Gang-Related Homicides (OLS)

Estimated Gang Violence

\begin{tabular}{|c|c|c|c|c|c|c|}
\hline & (1) & (2) & (3) & (4) & $(5)$ & (6) \\
\hline (Intercept) & 5.2 & 5.1 & -40 & $310 * * *$ & 210 & 210 \\
\hline \multirow{3}{*}{ exposure US violence } & {$[9.2]$} & {$[7.2]$} & [34] & [110] & [140] & [140] \\
\hline & $74 * * *$ & $70 * * *$ & $160 * *$ & $130 * *$ & $120 * *$ & $120 * *$ \\
\hline & [26] & [19] & [80] & [52] & [53] & [53] \\
\hline \multirow{2}{*}{$\begin{array}{r}\text { exposure housing } \\
\text { costs }\end{array}$} & & & & & 1.3 & 1.3 \\
\hline & & & & & [1.6] & [1.6] \\
\hline exposure Latin & & & & & 100 & 100 \\
\hline population & & & & & {$[160]$} & {$[160]$} \\
\hline \multirow{2}{*}{$\begin{array}{r}\text { historical homicide } \\
\text { rates }\end{array}$} & & & & $-6.2 * *$ & $-6.5 * * *$ & $-6.8 * * *$ \\
\hline & & & & [2.5] & [2.5] & {$[2.5]$} \\
\hline \multirow[t]{2}{*}{ analphabetism } & & & & 91 & 110 & 110 \\
\hline & & & & {$[83]$} & [84] & {$[87]$} \\
\hline \multirow[t]{2}{*}{ child work } & & & & 150 & 160 & 160 \\
\hline & & & & [130] & {$[130]$} & {$[140]$} \\
\hline \multirow[t]{2}{*}{ population size } & & & & $-25 * * *$ & $-24 * * *$ & $-24 * * *$ \\
\hline & & & & {$[7.6]$} & {$[7.3]$} & {$[7.2]$} \\
\hline \multirow[t]{2}{*}{ population density } & & & & 0.0044 & 0.0046 & 0.0089 \\
\hline & & & & {$[0.0058]$} & {$[0.0059]$} & {$[0.02]$} \\
\hline \multirow[t]{2}{*}{ housing quality } & & & & -110 & -110 & -100 \\
\hline & & & & [69] & [66] & [67] \\
\hline \multirow[t]{2}{*}{ household size } & & & & -19 & -19 & -19 \\
\hline & & & & [15] & [14] & [15] \\
\hline \multirow[t]{2}{*}{ emigration } & & & & -210 & $-220 *$ & $-220 *$ \\
\hline & & & & [130] & [120] & [120] \\
\hline \multirow[t]{2}{*}{ remittances } & & & & 190 & 190 & $190 *$ \\
\hline & & & & {$[120]$} & [120] & {$[120]$} \\
\hline \multirow{3}{*}{$\begin{array}{r}\text { department fixed } \\
\text { effects } \\
\text { sample }\end{array}$} & no & no & yes & yes & yes & yes \\
\hline & & & & & & \\
\hline & full & $\begin{array}{l}\text { pop }> \\
10^{\wedge} 3\end{array}$ & full & full & full & $\begin{array}{l}\text { excl. San } \\
\text { Salvador }\end{array}$ \\
\hline \multirow{2}{*}{$\begin{array}{l}\text { degrees of freedom } \\
\text { precision weights }\end{array}$} & 253 & 112 & 240 & 227 & 225 & 207 \\
\hline & no & no & yes & yes & yes & yes \\
\hline F-stat & 22.33 & 12.29 & 7.85 & 9.91 & 9.26 & 8.94 \\
\hline $\mathrm{R}^{\wedge} 2$ & 0.08 & 0.1 & 0.31 & 0.5 & 0.51 & 0.51 \\
\hline $\operatorname{adj} . R^{\wedge} 2$ & 0.08 & 0.09 & 0.27 & 0.45 & 0.45 & 0.45 \\
\hline
\end{tabular}

Heteroscedastic robust standard errors are given in squared brackets. The dependent variable is an estimation of gang-related killings, proxied by the drop in homicides during the truce between rivaling gang members. Stars denote statistical significance at $10 \%(*), 5 \%(* *)$ and $1 \%(* * *)$. See text for details 
Figure 5: Exposure to US Crime and Predicted Gang Violence

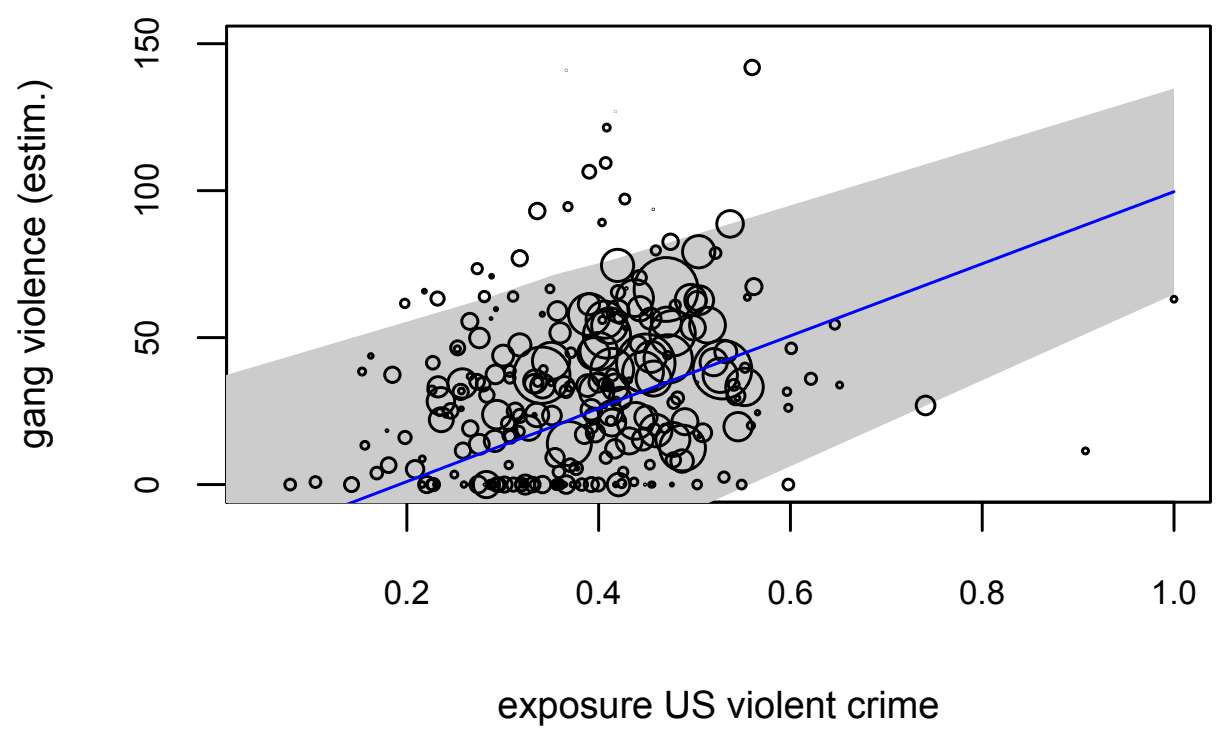

The figure draws the predicted effect of migrants' average exposure to US violence (normalized) on gang-related killings, based on specification (5) in Table 1, with a 95\% confidence interval. Larger circles refer to more populated municipalities, that are given a larger precision weight in the regression. 
Table 2: Exposure to US Violence and Gang-Related Homicides (OLS, Alternative Specifications) Estimated Gang Violence

\begin{tabular}{|c|c|c|c|c|c|}
\hline & (1) & $(2)$ & (3) & (4) & $(5)$ \\
\hline (Intercept) & $280 * *$ & 210 & $360 * * *$ & $390 * * *$ & $390 * * *$ \\
\hline \multirow{3}{*}{ exposure US violence } & {$[140]$} & {$[150]$} & [130] & {$[130]$} & {$[130]$} \\
\hline & $92 * *$ & $97 * *$ & & & \\
\hline & {$[42]$} & {$[43]$} & & & \\
\hline \multirow[t]{2}{*}{ Los Angeles } & & -120 & 55 & & \\
\hline & & [90] & [51] & & \\
\hline \multirow[t]{2}{*}{ Long Island } & & 9.8 & & -23 & \\
\hline & & [58] & & [48] & \\
\hline \multirow[t]{2}{*}{ Washington } & & 69 & & & -0.042 \\
\hline & & {$[46]$} & & & {$[37]$} \\
\hline \multirow[t]{2}{*}{ exposure housing costs } & 1.1 & 1.9 & & & \\
\hline & [1.4] & {$[1.8]$} & & & \\
\hline \multirow[t]{2}{*}{ exposure Latin population } & 60 & $420 *$ & & & \\
\hline & {$[150]$} & {$[250]$} & & & \\
\hline pre-treatment ctrls. (1992) & yes & yes & yes & yes & yes \\
\hline additional ctrls. (2007) & yes & yes & no & no & no \\
\hline department fixed effects & yes & yes & yes & yes & yes \\
\hline sample & full & full & full & full & full \\
\hline degrees of freedom & 220 & 217 & 227 & 227 & 227 \\
\hline precision weights & yes & yes & yes & yes & yes \\
\hline F-stat & 9.31 & 8.78 & 7.68 & 7.57 & 7.55 \\
\hline $\mathrm{R}^{\wedge} 2$ & 0.56 & 0.57 & 0.44 & 0.43 & 0.43 \\
\hline adj. $R^{\wedge} 2$ & 0.5 & 0.51 & 0.38 & 0.38 & 0.38 \\
\hline
\end{tabular}

Heteroscedastic robust standard errors are given in squared brackets. The dependent variable is an estimation of gang-related killings, as described in the text. Additional post-treatment controls include an average of per capita value added tax paid in each municipality over the periods 2001 to 2012 (Ministerio de Hacienda, Dirección de Impuestos Internos), the share of household with emigrants as well as the share of households receiving remittances as reported in the 2007 census (Digestyc, Censo de Población y Vivienda 2007), and the 2005 poverty head count at the municipal level FISDL-FLACSO (2005). Pre-treatment controls refer to all controls included in Table 1, based on the 1992 census. Stars denote statistical significance at 10\% (*), $5 \%(* *)$ and $1 \%(* * *)$. 
Table 3: Annual Deportations and Homicide Rates at the Municipal Level. Panel Results (OLS)

Homicides per capita

exposure US violence*inflow of convicts

(1)

(2)

$0.45^{* * *}$

$0.45^{* * *}$

[0.12]

(4)

exposure US violence*truce

$[0.12]$
$-66 * * *$

$0.85 *$

$1.2 * * *$

(5)

[0.46]

[0.46]

$-83 * *$

$0.75^{* *}$

[54]

[33]

$-59 * *$

$1.2 * * *$

(7)

[15]

[25]

0.25

exposure US violence*inflow of non-convicts

value addec tax per capita

population size

municipality fixed effects

year fixed effects

precision weights

degrees of freedom

$$
\text { sample }
$$

full sample

yes
yes
no
3555
cl. $2012 / 13$
ull sample

$\begin{array}{cc}\text { yes } & \text { yes } \\ \text { yes } & \text { yes } \\ \text { no } & \text { yes } \\ 4062 & 4062 \\ \text { 999-2015 } & 1999-2015 \\ \text { ll sample } & \text { full sample }\end{array}$

\begin{tabular}{cccc} 
& {$[0.2]$} & & \\
-0.0095 & -0.0095 & -0.011 & $-0.0042 * *$ \\
{$[0.0061]$} & {$[0.0061]$} & {$[0.0068]$} & {$[0.0017]$} \\
$-6 \mathrm{e}-04 * * *$ & $-6.10 \mathrm{e}-04 * * *$ & -0.00073 & $-0.00023 * * *$ \\
{$[0.00023]$} & {$[0.00023]$} & {$[0.00051]$} & {$[8 \mathrm{e}-05]$} \\
\hline yes & yes & yes & yes \\
yes & yes & yes & yes \\
yes & yes & yes & yes \\
3502 & 3501 & 3236 & 1746 \\
$1999-2015$ & $1999-2015$ & $1999-2015$ & $1999-2015$ \\
full sample & full sample & w/o San & two-year means \\
& & Salvador & full sample
\end{tabular}

\begin{tabular}{|c|c|c|c|c|c|c|c|}
\hline $\mathrm{T}$ & 14 & 14 & 14 & 16 & 16 & 16 & 8 \\
\hline $\mathrm{R}^{\wedge} 2$ & 0.47 & 0.45 & 0.32 & 0.38 & 0.38 & 0.37 & 0.56 \\
\hline $\operatorname{adj} . R^{\wedge} 2$ & 0.43 & 0.41 & 0.28 & 0.33 & 0.33 & 0.33 & 0.49 \\
\hline F-stat & 11.67 & 12.21 & 7.15 & 7.89 & 7.89 & 7.67 & 8.23 \\
\hline
\end{tabular}

Heteroscedastic robust standard errors are given in squared brackets. Stars denote statistical significance at $10 \%(*), 5 \%(* *)$ and $1 \%(* * *)$. See text for details 


\section{Literature}

Acevedo, Carlos. 2008. "The Economic Costs of Violence in El Salvador." América Latina Hoy 50: 71-88.

Anselin, Luc, Jacqueline Cohen, David Cook, Wilpen Gorr, and George Tita. 2000. "Spatial Analyses of Crime." Criminal Justice 4 (2): 213-262.

Anzoategui, Diego, Asli Demirgüç-Kunt, and María Soledad Martínez Pería. 2014.

"Remittances and Financial Inclusion: Evidence from El Salvador." World

Development 54 (February): 338-49. https://doi.org/10.1016/j.worlddev.2013.10.006.

Arana, Ana. 2005. "How the Street Gangs Took Central America." Foreign Aff. 84: 98.

Baller, Robert D., Luc Anselin, Steven F. Messner, Glenn Deane, and Darnell F. Hawkins. 2001. "Structural Covariates of US County Homicide Rates: Incorporating Spatial Effects." Criminology 39 (3): 561-588.

Banco Central de Reservas (BCR) de El Salvador. 2016. “Estimación Del Costo Económico de La Violencia En El Salvador 2014.” San Salvador.

Blake, Garfield O. 2014. “America’s Deadly Export: Evidence from Cross-Country Panel Data of Deportation and Homicide Rates." International Review of Law and Economics 37: 156-168.

Buergenthal, Thomas. 1994. "The United Nations Truth Commission for El Salvador." Vand. J. Transnat'l L. 27: 497.

Carcach, Carlos Alberto. 2008. "El Salvador. Mapa de Violencia y Su Referencia Historica." San Salvador: Centro de monitoreo y evaluación de la violencia desde la perspectiva ciudadana.

Clemens, Michael A. 2017. "Violence, Development, and Migration Waves: Evidence from Central American Child Migrant Apprehensions.” Working Paper 459. Washington, D.C.: Center for Global Development.

Cox Edwards, Alejandra, and Manuelita Ureta. 2003. "International Migration, Remittances, and Schooling: Evidence from El Salvador.” Journal of Development Economics 72: 429-61. 
Cruz, José Miguel. 2013. "Beyond Social Remittances. Migration and Transational Gangs in Central America." In How Migrants Impact Their Homelands, Susan Eckstein and Adil Najam, 213-33. Duke University Press.

Cruz, José Miguel, and Nelson Portillo Peña. 1998. Solidaridad y Violencia En Las Pandillas Del Gran San Salvador: Más Allá de La Vida Loca. Vol. 9. Uca Editores.

Digestyc. 1996. "Proyección de Población Por Año Calendario, Según Departamento, Municipio y Sexo. 1995-2010.”

Digestyc, UNFPA, and CEPAL. 2014. "Estimaciones y Proyecciones de Población.”

Dirección General de Estadística y Censos (Digestyc). 2015. "Medición Multidimensional de La Pobreza." Secretaría Técnica y de Planificación de la Presidencia y Ministerio de Economía, a través de la Dirección General de Estadística y Censos.

Dunn, William Carl. 2007. The Gangs of Los Angeles. iUniverse.

FISDL-FLACSO. 2005. Documento Mapa de La Pobreza. Tomo I. Política Social y Focalización. Edited by Fondo de Inversión Social para el Desarrollo Local (FISDL) and Facultad Latinoamericana de Ciencias Sociales (FLACSO) El Salvador. San Salvador.

Gammage, Sarah. 2006. "Exporting People and Recruiting Remittances. A Development Strategy for El Salvador?" Latin American Perspectives 6 (3): 75-100.

Hagedorn, John. 2008. A World of Gangs: Armed Young Men and Gangsta Culture. Vol. 14. U of Minnesota Press.

Hinojosa, Raúl. 2011. "El Salador-United States Transnational Corridors GIS Interactive Atlas." UCLA-NAID.

Howell, James C. 2015. The History of Street Gangs in the United States: Their Origins and Transformations. Lexington Books.

Howell, James C., and John P. Moore. 2010. "History of Street Gangs in the United States." National Gang Center Bulletin 4 (May).

Kilsi, Patri. 2017. "The Impact of U.S. Deportation of Criminals on Gang Development and Education in El Salvador." unpublished manuscript.

Latinobarómetro. 2017. “Informe 2017.” Buenos Aires. 
Lineberger, Kelly Padgett. 2011. "The United States-El Salvador Extradition Treaty: A Dated Obstacle in the Transnational War against Mara Salvatrucha (MS-13)." Vand. J. Transnat'l L. 44: 187.

Martínez, Carlos, and José-Luis Sanz. 2012a. "El Origen Del Odio.” El Faro, June 8, 2012, sec. Sala Negra.

—. 2012b. "La Letra 13.” El Faro, June 8, 2012, sec. Sala Negra.

Martínez, Óscar, Carlos Martínez, Sergio Arauz, and Efren Lemus. 2012a. “Gobierno Negoció Con Pandillas Reducción de Homicidios.” El Faro, March 14, 2012.

_. 2012b. "Government Negotiates Reduction in Homicides with Gangs." El Faro, March 14, 2012, sec. Sala Negra.

Maslin, Sarah Esther. 2017. "La Política de Deportación de Estados Unidos Está Avivando La Violencia de Las Pandillas." VICE, no. June 16th.

Migration Policy Institute (MPI). 2010. "Salvadoran Immigrants in the United States."

Pew Research Center. 2015. "Hispanics of Salvadoran Origin in the United States, 2013. Statistical Profile.” Washington, D.C.

Rodgers, Dennis, Robert Muggah, and Chris Stevenson. 2009. Gangs of Central America: Causes, Costs, and Interventions. Small Arms Survey Geneva.

Savenije, Wim. 2009. Maras y Barras: Pandillas y Violencia Juvenil En Los Barrios Marginales de Centroamérica.

Savenije, Wim, and Katharine Andrade-Eekhoff. 2003. Conviviendo En La Orilla. Violencia y Exclusión Social En El Área Metropolitana de San Salvador.

Seelke, Clare Ribando. 2011. "Gangs in Central America." Current Politics and Economics of South and Central America 4 (1): 67.

Smutt, Marcela, and Jenny Lissette E. Miranda. 1998. El Fenómeno de Las Pandillas En El Salvador. FLACSO and UNICEF.

US Census Bureau. 2017. "USA Counties Online Databases.”

Valencia, Roberto. 2015. "La Tregua Redefinió El Mapa de Asesinatos de El Salvador.” El Faro, September 3, 2015.

Vigil, Diego. 2010. A Rainbow of Gangs: Street Cultures in the Mega-City. University of Texas Press. 
World Bank. 2017. "World Development Indicators Online Database."

Zuñiga Nuñez, Mario. 2016. "Migración, Pandillas y Criminalización: La Conflictividad Social Estadounidense y Su Relación Con El Salvador." In Migraciones En América Central, Carlos Sandoval García, 25-46. 


\section{Annex}

\section{Annex 1: Data Description and Sources}

\section{A) Cross-sectional data}

VARIABLE
gang-related violence

DESCRIPTION

Mean [s.d.] between rivaling gangs $(03 / 2012$ to $03 / 2013)$ and homicide rates before and after the truce $(01 / 2009$ to $12 / 2015)^{\text {c) }}$

exposure US violence

Los Angeles

Washington

Long Island

exposure housing costs

exposure Latin population

historical homicide rates

analphabetism

child work

population density

population size

housing quality
Average exposure of migrants from municipality $j$ to crime rates at US destination county $\mathrm{i}$, normalized to $[0,1]$. Crime rates are defined as violent crime known to police, including murder \& non-negligent manslaughter, legacy rape, revised rape, robbery, and aggravated assault. Crime data at the US county level refers to 1981 . ${ }^{\text {a) }}$ )

Share of migrants from each municipality $\mathrm{j}$ in Los Angeles county ${ }^{\text {a) }}$

Share of migrants from each municipality $\mathrm{j}$ in the Washington D.C. area ${ }^{\text {a) }}$

Share of migrants from each municipality $\mathrm{j}$ in Long Island (counties Suffolk and Nassau) ${ }^{\text {a) }}$

Average exposure of migrants from municipality $j$ to housing costs at US destination county i. Housing costs are defined as valuation of new private housing units authorized by building permits 1980 (in thsnd. USD) ${ }^{\text {a) }}$ )

Average exposure of migrants from municipality $j$ to the size of Latin origin population at US destination county $i$ in the year 1980, measured as the share of Latin origin population of total population ${ }^{\text {a) } f}$

Homicide rates per 100 thsnd. as reported in the printing press, as an average over the years 1965 , 1975 and 1995 (logged in the regression) ${ }^{\mathrm{g})}$ phare of households in 1992 in which at least one how to read or write ${ }^{\text {d) }}$

Population density in 1992, defined as population size in 1992 per square kilometer ${ }^{\text {d) }}$

Total population size of municipality in 1992 (logged in the regression) ${ }^{d)}$

Averages of a composite indicator of housing quality from the 1992 census, gives equal weight to four binary indicators: Whether tenure was uncertain, whether housing was overcrowded, whether roof was in a bad shape, and whether floors 


\begin{tabular}{|c|c|c|}
\hline & $\begin{array}{l}\text { were in a bad shape. Higher values indicate worse } \\
\text { housing conditions } \mathrm{d})\end{array}$ & \\
\hline household size & $\begin{array}{l}\text { Average number of persons living in a household in } \\
1992^{\mathrm{d})}\end{array}$ & $\begin{array}{l}6.3 \\
{[0.42]}\end{array}$ \\
\hline emigration & $\begin{array}{l}\text { Share of households in } 1992 \text { in which a member } \\
\text { lived in a different country d) }\end{array}$ & $\begin{array}{l}0.13 \\
{[0.077]}\end{array}$ \\
\hline remittances & $\begin{array}{l}\text { Share of households in } 1992 \text { that had received } \\
\text { international remittances during the previous } 12 \\
\text { months }{ }^{\text {d) }}\end{array}$ & $\begin{array}{l}0.15 \\
{[0.084]}\end{array}$ \\
\hline
\end{tabular}

\section{B) Annual data}

$\begin{array}{cl}\text { homicides } & \begin{array}{l}\text { Annual homicide rates at the municipal level per } \\ 100 \text { thsnd. (1999 to 2015) }\end{array} \\ \text { per capita VAT } & \begin{array}{l}\text { Value added text per capita at the municipal level } \\ (2001 \text { to } 2015)^{\mathrm{i})}\end{array} \\ \text { population size } & \begin{array}{l}\text { Population projections at the municipal level (1999 } \\ \text { to 2015) }\end{array}\end{array}$
37

65

The table provides mean values and standard deviations in squared brackets for a maximum of 262 Salvadoran municipalities. Sources: ${ }^{\text {a) }}$ NAID at UCLA, see Hinojosa (2011); ${ }^{\text {b) }}$ US Department of JusticeFederal Bureau of Investigation, via US Census Bureau (2017); ${ }^{\mathrm{c}}$ Mesa tripartida (Policia Nacional, the Instituto de Medicina Legal and the public prosecutor's department fiscalía) in El Salvador ${ }^{\text {d) }}$ Digestyc, Censo de Población y Vivienda 1992; ${ }^{\text {e) }}$ Construction Division of the US Census, via Census Bureau (2017); f) 1980 Population Census, via US Census Bureau (2017); ${ }^{\text {g) }}$ Carcach (2008); ${ }^{\text {h) }}$ Instituto de Medicina Legal de El Salvador. Anuarios Estadísticos. Varios Años ${ }^{\text {i) }}$ Ministerio de Hacienda de El Salvador, Dirección de Impuestos Internos; ${ }^{\mathrm{j})}$ Digestyc/UNFPA/Cepal, Estimaciones y Proyecciones de Población. Municipal 20052025 (San Salvador, 2014); and Digestyc, Proyección de Población por año calendario, según departamento, municipio y sexo. 1995-2010 (San Salvador, 1996) 
Annex 2: Exposure to US Violence and Gang-Related Homicides (Tobit MLE and Spatial Lag Model)

Estimated Gang Violence

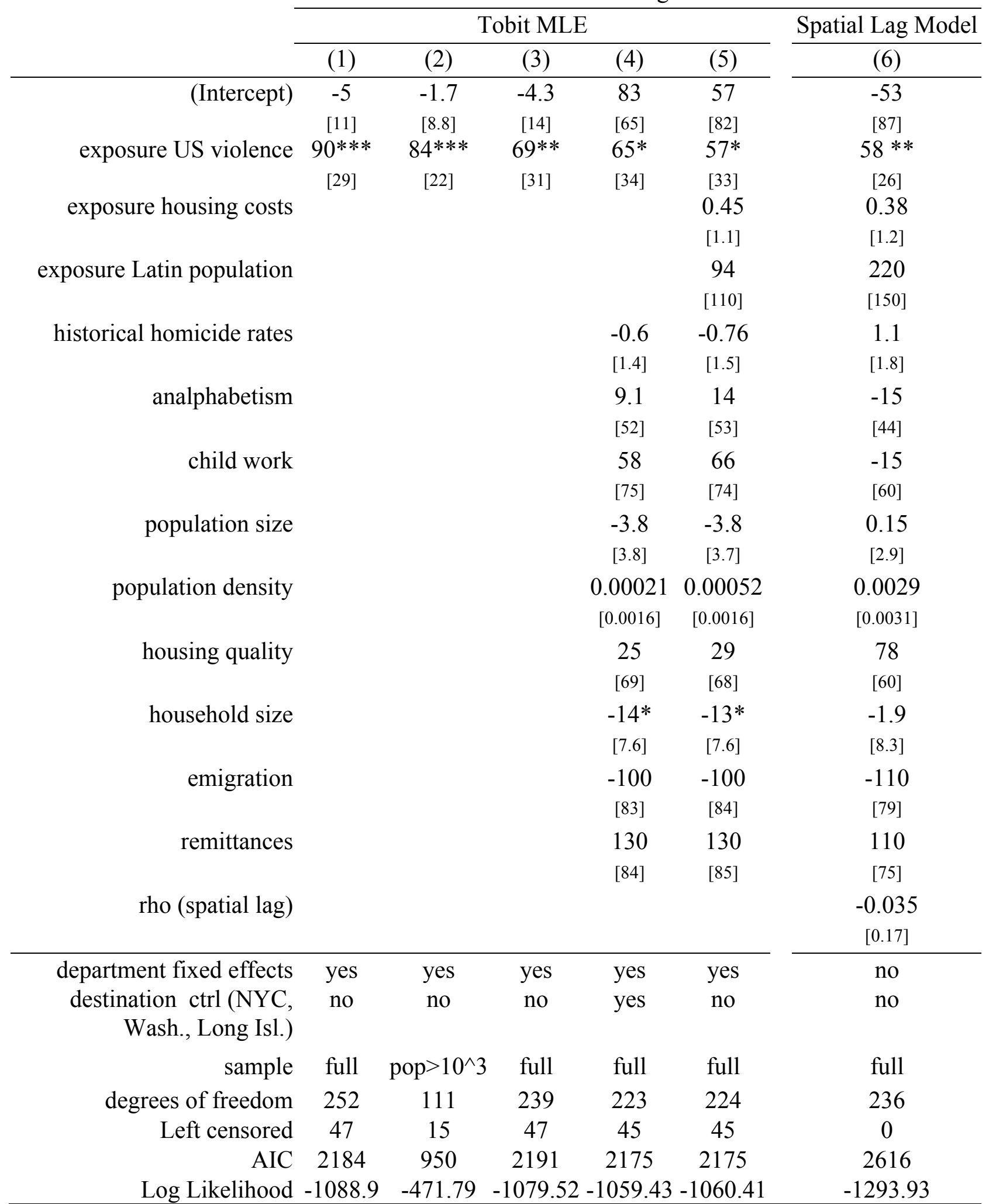

Tobit MLE uses a left-truncated dependent variable. The spatial lag model takes into account possible correlation of violence between $\mathrm{k}$ municipalities sharing common borders. Then, a binary weighting matrix is applied to the list of neighbors in order to identify spatial lags for each municipality $\mathrm{j}$. Heteroscedastic robust standard errors are given in squared brackets. The dependent variable is an estimation of gang-related killings (drop in homicide rates during truce). Stars denote statistical significance at $10 \%(*), 5 \%(* *)$ and $1 \%(* * *)$ 


\section{Diskussionsbeiträge - Fachbereich Wirtschaftswissenschaft - Freie Universität Berlin Discussion Paper - School of Business and Economics - Freie Universität Berlin}

2018 erschienen:

2018/1 BESTER, Helmut und Ouyang YAOFU

Optimal Procurement of a Credence Good under Limited Liability Economics

2018/2 GROß, Markus, Ulrich RENDTEL, Timo SCHMID und Nikos TZAVIDIS

Switching between different area systems via simulated geo-coordinates: a case study for student residents in Berlin

Economics

2018/3 GROß, Markus, Ulrich RENDTEL, Timo SCHMID, Hartmut BÖMERMANN und Kerstin ERFURTH

Simulated geo-coordinates as a tool for map-based regional analysis

Economics

2018/4 KONYUKHOVSKIY, Pavel V. und Theocharis GRIGORIADIS

Proxy Wars

Economics

2018/5 FOX, Jonathan F. und Theocharis GRIGORIADIS

A Rural Health Supplement to the Hookworm Intervention in the American South

Economics

2018/6 VITOLAS,Alise und Theocharis GRIGORIADIS

Diversity \& Emipre: Baltic Germans \& Comparative Development

Economics

2018/7 GAENTZSCH, Anja

The distributional impact of social spending in Peru

Economics

2018/8 SCHREIBER, Sven

Are bootstrapped conintegration test findings unreliable?

Economics

2018/8 SCHREIBER, Sven

Are bootstrapped conintegration test findings unreliable?

Economics

2018/9 GRIGORIADIS, Theocharis

Aristotle vs. Plato: The Distributive Origins of the Cold War

Economics 
2018/10 WALTER, Paul und Katja WEIMER

Estimating Poverty and Inequality Indicators using Interval Censored Income Data from the German Microcensus

Economics

2018/11 BESTER, Helmut; Matthias LANG und Jianpei LI

Signaling versus Costly Information Acquisition

Economics 